\title{
Digital Spaces and Bi-Regional Interaction within the Paradigm of Scientific Cooperation
}

\author{
Rosa Iosifovna Sitdikova ${ }^{1}$, Nataliya Yevgenjevna Tyurina ${ }^{2}$, Liliia Djamilovna Iafizova ${ }^{3}$ \\ ${ }^{1}$ Kazan Federal University, Doctor of Law, Professor, Law Faculty, Department of Business and Energy Law, \\ Researcher ID: I-5126-2016, ORCID: 0000-0003-1715-2863 \\ ${ }^{2}$ Kazan Federal University, Doctor of Law, Professor, Law Faculty, Department of International and European Law, \\ ORCID: 0000-0001-9302-4527
}

${ }^{3}$ Kazan Federal University, Training specialist, Law Faculty, Scientific and educational center for Human Rights, International Law and integration problems, ORCID: 0000-0001-7973-5170

\begin{abstract}
Scientific cooperation takes an increasing place in the problems of international law, which is quite understandable in the context of the ever-increasing interdependence of modern states. The expectations of the international community associated with scientific discoveries pose new challenges in the field of legal regulation of relations on cooperation between states in this area. The solution of these problems affects such issues as the determination of the legal status of information spaces, intellectual property, and the regulation of regional and interregional relations. This paper examines the legal aspects of international cooperation in order to prevent and overcome threats to life and health of people by expanding the geography of scientific exchanges and obtaining timely access to the results obtained from all stakeholders. The digitalization of the regional scientific space and the use of digital resources for the creation of innovative products and interregional information exchange are presented as a necessary condition for the implementation of international cooperation in this area. The necessity of improving international legal regulation in the field of intellectual property protection based on the provisions of TRIPS (WTO) on assistance in the provision of medicines by concluding an agreement on an international patent for medical products for global emergencies has been substantiated. It is proposed to focus on the establishment of interregional cooperation in the field of scientific research using the model of the regional scientific space.
\end{abstract}

Key words: regional cooperation, scientific space, interregional interaction, globalization, digital space.

\section{INTRODUCTION}

In the current situation, attention has increased to scientific results on the creation of drugs against a viral infection. The problem of Covid-19, which humanity unexpectedly faced, has become so widespread due to circumstances related to the process of globalization. Disclosing the content of this concept, researchers note numerous manifestations of globalization and agree that this is a tendency of world development. It is intensifying with the growth of progressive changes due to innovative technologies, the ever-increasing rates of information dissemination, the increase in migration flows and other types of mobility. With all the diversity of the current manifestations of globalization, one can note a single common result that is already taking place and the degree of which is steadily increasing: this is the interdependence of states [1].

Initially, interdependence is based on the objective factor of uneven distribution of natural resources, which predetermined the formation of international trade and, in the future, economic cooperation in other forms. It is interdependence as an objective given as an expression found in the relations of separate territories (from armed clashes to support and mutual assistance) that served as a material source for the emergence of international law. At present, factors of interdependence, along with economic needs, are such circumstances as a nuclear threat, anthropogenic man-made threats, as well as natural disasters that arise independently of a person or are a result of this impact on a natural object. The consequences of these circumstances are problems that threaten the health and life of people anywhere in the world, regardless of political boundaries. In such conditions, special expectations are associated with scientific discoveries that can neutralize these threats. The collaboration of scientists in the search for solutions to global problems of this kind, in providing access to the results obtained, can give a chance to overcome disasters that pose a universal danger.

The COVID-19 pandemic has clearly shown that the focus of international law should be on cooperation in preventing and overcoming common human problems that are accidents of nature, but potentially solvable based on scientific and engineering achievements. It also revealed the urgent need for innovative forms of scientific cooperation and the exchange of scientific results in the interests of all mankind. In accordance with the instruction of the General Conference of UNESCO in November 2019, this organization began to develop a recommendation on open science, the relevance of which has increased many times over the current period. The key issues, in the context of the COVID-19 pandemic at the UNESCO online meeting on March 30, 2020 with the participation of 122 representatives, were: discussing the role of international scientific cooperation, increasing investment in the field of science, and effective exchange of information [2]. 


\section{METHODS}

This paper analyzes the problems identified in connection with the designated events, using formal legal, comparative legal and systemic research methods and using general theoretical and special industry legal categories.

\section{RESULTS AND DISCUSSION}

\section{Digitalization of the information space}

In light of solving the problem of effective information exchange, which is an important element of international scientific cooperation, a special role should be played by scientific spaces, which today are unthinkable otherwise than digital. The general digitalization of all sectors of the economy and public life opens up new opportunities for scientific and technical cooperation. First of all, it should be noted here the wide possibilities of access to various information resources and to information exchange of scientific and technical information.

Many researchers note the possibility of creating a new generation of digital platforms as a characteristic feature of the digital economy, where knowledge and information are accumulated in a specific area. Moreover, such platforms allow participants to directly communicate and exchange information without the participation of any intermediaries or regulatory bodies of a state or supranational nature. Such platforms are already being created in the field of scientific and technical cooperation; this process is especially active at the regional level, in particular in the CIS and the European Union. Such platforms include, for example, a unified database of regulatory legal acts of regional associations, a database of statistical data and research results that are available to all members of the respective union. Provided that a system of exchange between such platforms and research teams is created, we can talk about creating a digital research space. Certain elements of such a research space are already successfully functioning: in particular, the system of interlibrary exchange in the CIS, and the possibility of converting information and works into digital form, together with the introduction of modern communication technologies make it possible to create a modern platform for scientific and technological cooperation in this area. Since 2000, the European Research Area has been formed in the European Union as an example of the so-called "knowledge economy" in the modern world [3]. Information and the ability to legally access it are keys to build a "knowledge economy" or "knowledge society". The term "information society" is widely used. In the Russian Federation, the Strategy for the Development of the Information Society in the Russian Federation for 2017 - 2030 was adopted on the basis of the Decree of the President of the Russian Federation [4]. The widespread adoption of digital technologies gives a new impetus to the formation of the information society and research spaces. All this contributes to the development of communication links between research teams and individual scientists, as well as to the integration of scientists from individual countries into an international scientific space, which is now increasingly functioning as a digital one. The above-mentioned Decree of the President of the Russian Federation defines the information space: according to the Decree, it is "a set of information resources created by subjects of the information sphere, means of interaction between such subjects of their information systems, and also by the necessary information infrastructure." Based on this definition, the modern regional digital scientific space can be defined as a set of regional digitized information resources and subjects of scientific and technological activity united by modern telecommunication means.

The role of international digital spaces can hardly be overestimated in situations requiring joint decisions based on newly created scientific products.

\section{Issues of intellectual property protection}

The general legal basis for relations between states for solving global problems is formed by the universally recognized principles of international law. At the same time, the specificity of a particular situation requires the use of additional legal instruments. Thus, under the current circumstances qualified by WHO as a pandemic of the COVID-19 virus infection the WTO TRIPS provisions became actual. They were established by the Protocol "On Amendments to the Agreement on Trade-Related Aspects of Intellectual Property Rights", which was adopted by the decision of the WTO General Council (WT / L / 641) dated December 6, 2005 and on January 23, 2017 they entered into force.

The amendment referred to in the Protocol is the inclusion in TRIPS of a new article, which gives the right to WTO members with insufficient drug production capacity to turn to another WTO member in case of an emergency for help in securing the required amount of drugs. At the same time, the WTO member who has agreed to provide such assistance has the right to use a compulsory license to create a generic drug for the purpose of its further export to the country in need, subject to a number of restrictive requirements. It is also possible to apply for the issuance of a compulsory license in other circumstances of extreme necessity or for the purpose of non-commercial use by the state of the object of patent rights. In these circumstances, a WTO member issuing a compulsory license has immunity if it is necessary to challenge its actions by other WTO members [5].

The obligations stipulated by this document certainly meet the needs of combating the pandemic, but at the same time, gaps are identified associated with the uniqueness of the current situation, which is expressed in the following: the need for a medicine does not exist in a single state, but in all countries without exception; the required drug can be a drug (a treatment for a disease that has arisen) or a prophylactic agent; along with the export of a manufactured drug, the provision of a compulsory license for its production is of fundamental importance not only in the country where the license was issued, but also in other states. At the same time, the granting of such a license to a manufacturer located in a state where the corresponding patent is not valid, due to the limited validity of the territory of the issuing country, entails commercial risks for the patent holder. In conditions when there is a need for large volumes of production and the issuance of a compulsory 
license to a foreign manufacturer becomes logical, additional tools for protecting patent rights are needed. The most reliable of these would be a universal international patent. At the same time, the provision on a compulsory license formulated in Article 12 of the Eurasian Patent Convention of 1994 could be used in relation to a compulsory license for an invention confirmed by a universal international patent. The fundamental point in this provision is that compulsory licenses issued by the competent authority of a Contracting State are valid in the territory of that State [6]. However, since the establishment of the institution of a universal patent is associated with a significant reform of the international system for the protection of intellectual rights, the movement in this direction will be quite long and gradual. In particular, the beginning could be laid by the conclusion of a multilateral agreement on an international patent for medical products designed for global emergencies. At the same time, taking into account the impact of regional processes on international (universal) ones, it is advisable to make the most of the possibilities of regional scientific spaces in solving common problems [7].

\section{Interregional cooperation}

Scientific cooperation within the framework of regional spaces has already proved its effectiveness by the example of a number of relevant international (regional) organizations [8] and it is characterized as a factor of positive impact on integration processes [9]. Regional organizations act as independent participants in relations with other subjects of international law, including with organizations of their own kind. In connection with the need to obtain scientific results of general interest, the development of interregional interaction is of particular relevance, especially since it is already in the focus of certain areas of international relations [10] and it has manifested itself as a promising form of scientific and technical cooperation [11]. The legal model of the interregional scientific space for new entities can be based on the practice of regional relations in this area, taking into account the characteristics of the interacting subjects.

So, the legal registration of the interregional scientific space requires the conclusion of an agreement between the bodies personifying the regional space and endowed with the necessary powers. In the CIS, the Council of Foreign Ministers is empowered to consider and make decisions on cooperation with international organizations. Despite the fact that the practice of concluding relevant agreements is very limited, examples of such agreements are known: these are agreements on cooperation with UNCTAD in 1994, with the UN Economic Commission for Europe (UNECE) in 1996. Those agreements allow us to speak of the possibility of forming a contractual basis for interregional scientific cooperation. Another form that has become widespread in the practice of regional cooperation can be joint projects and research programs that provide for the creation of interregional centers, laboratories, test sites, as well as development teams, and mechanisms for information exchange between them through electronic communications and mobility. Non-governmental bodies with the participation of organizations of the academic community and academic mobility are called upon to play a special role there.
In general, the interregional scientific space materializes in relations between regional international organizations represented by bodies that are empowered to coordinate research policies and functions to implement international treaties in this area, in relations between joint and national scientific organizations and institutions of the participating states, and in relations between researchers (direct executors of scientific programs) in the form of joint scientific events of a theoretical and practical nature. Its integral part is the digital component.

The specified format is also of interest from the point of view of its implementation in production and use of scientific research results. In addition, a way is seen also in interregional cooperation (as its scope expands) to increase the role of regional organizations within the paradigm of international law, however, it is assessed in even the latest scientific publications as very modest. [12]

\section{SUMMARY}

Scientific cooperation as a sphere that provides the means for the survival of mankind should be among the priority areas of interstate interaction. The essential conditions for the effectiveness of scientific activity in order to meet the relevant needs are, among others: the development of international digital spaces, the improvement of international legal regulation of intellectual rights in the public interest, and the creation of an international network of scientific communities, in particular, through interregional cooperation.

\section{CONCLUSIONS}

The global problem in the face of a pandemic that ignores any boundaries makes us look in a new way at the world as a whole, and at the role of international law in this world. The problem forms additional elements in the system of universal values and indicates the priorities of the modern international community. Ignoring the objective reality that determines these priorities is fraught with irreparable consequences. The particular legal issues raised in this paper by no means exhaust the multifaceted problematics of non-anthropogenic common human threats. Perhaps, this will serve as a certain contribution to the results of the scientific discussion "Pandemic and International Law", which is already underway [13] and will be continued in more the wider context of global problems.

\section{ACKNOWLEDGEMENTS}

The work is performed according to the Russian Government Program of Competitive Growth of Kazan Federal University. The reported study was funded by RFBR according to the research project № 18-29-15046 


\section{REFERENCES}

[1] Michaels R. Globalization and law: law beyond the state. Law and Social Theory (Banakar \& Travers eds., Oxford, Hart Publishing, 2013), Forthcoming. 2013 Mar 15.

[2] In the context of COVID-19, UNESCO mobilizes 122 countries to promote open science and strengthen cooperation. WWW.UNESCO.ORG/ALMATY URL: http://ru.unesco.kz/unesco-mobilizes-122-countries-topromote-open-science-and-reinforced-cooperation-in-the (access date: 12.06.2020).

[3] Abdullin AI, Sitdikova RI, Tyurina NE, Iafizova LD. Institutional Framework for regional International Scientific and Technical cooperation in the CIS, the EAEU and the EC. AD ALTA-Journal of Interdisciplinary Research. - Special Issue - 09/02. - YIII. P.10-12.

[4] Decree of the President of the Russian Federation dated 09.05.2017 No. 203 "On the Strategy for the Development of the Information Society of the Russian Federation for 2017 - 2030". URL: http://kremlin.ru/acts/bank/41919 (access date: 13.06.2020).

[5] Protocol Amending the TRIPS Agreement (WT/L/641) dated December, 6, 2005 // URL: https://www.wto.org/english/tratop_e/trips_e/wtl641_e.ht $\mathrm{m}$ (access date: 11.06.2020).

[6] Eurasian Patent Convention (Moscow, September 9, 1994) // URL: https://rupto.ru/ru/documents/evraziyskaya-patentnayakonvenciya (access date 6.06.2020).

[7] Klučka J. Regionalism in International Law. 2018. New York: Routledge, https://doi.org/10.4324/9781315160108 (access date 6.06.2020).

[8] Abdullin AI, Sitdikova RI, Tyurina NE, Iafizova LD. Institutional Framework for regional International Scientific and Technical cooperation in the CIS, the EAEU and the EC. AD ALTA-Journal of Interdisciplinary Research. - Special Issue - 09/02. - YIII. P.10-12.

[9] Lino Barañao, Regional Scientific Education and the Integration of Latin America: A Perspective from Argentina. Science \& Diplomacy. 2016;5(3). http://www.sciencediplomacy.org/perspective. 2016. regional-scientific-education-andintegration-latin-america (access date 8.06.2020).

[10] Albergel J, Diaby N, Francis JA, Lançon J, Sers JM, Viljoen J. Bi-regional scientific cooperation on food and nutrition security and sustainable agriculture. InAfricaEurope Research and Innovation Cooperation 2018 (pp. 65-79). Palgrave Macmillan, Cham.

[11] Quental CM, de Souza Minayo M, Becerra-Posada F, López-Peñac T, Mourenza B, Buonocore C. The development of relationships in science, technology, research and innovation in health between the EU and
LAC countries: a promising future. Revista Eletrônica de Comunicação, Informação e Inovação em Saúde. 2014;8(1).

[12] Brölmann C. Interactions Between Regional and Universal Organizations: A Legal Perspective. By Laurence Boisson de Chazournes. Leiden: Brill| Nijhoff, 2017. Pp. xxv, 382. Index. American Journal of International Law. 2020 Apr;114(2):335-40.

[13] Durham Kh. On the Role of IHL in the COVID-19 Pandemic. URL: https://www.icrc.org/ru/document/helen-darem-o-rolimgp-v-usloviyah-pandemii-covid-19 (access date 13.06.20).

\section{Short biography}

Roza Iosifovna Sitdikova, Doctor of Law, Professor at the Department of Business and Energy Law of Kazan (Volga Region) Federal University; expert of the Russian Academy of Sciences. Research interests: legal regulation of the creation, protection and use (including in stream of commerce) of the results obtained due to intellectual activity and means of individualization (intellectual property) in the Russian Federation and at the international level.

Natalia Evgenievna Tyurina, Doctor of Law, Professor, Department of International and European Law at Kazan (Volga Region) Federal University. Head of the master's program "European and International Business Law". Member of the Russian Association of International Law. The main area of her research interests is international economic law. Author of over 100 scientific publications.

Lilia Jamilovna Yafizova, specialist at the Scientific and Educational Center for Human Rights, International Law and Integration Problems. The main area of her research interests is international law, international integration, and integration law. Member of the Association of Russian Lawyers. 